\title{
Case 1: A professional online exhibition platform as an example of final user's benefits
}

\author{
Joanna Duda* and Łukasz Lelek ${ }^{\dagger}$ \\ *PhD, AGH University of Science and Technology, Faculty of Management, \\ Krakow, Poland \\ ${ }^{\dagger}$ M.Sc. Eng., Mineral and Energy Economy Research Institute of The Polish \\ Academy of Sciences, Krakow, Poland
}

\section{Introduction}

From the earliest times, human life has involved the exchange of goods and services. Even before the rise of civilization, people formed the foundation for the market of goods. In ancient Rome and Greece, the form of exchange of goods and services were fairs. Currently fairs developed on a massive scale. Every year, thousands of events are organized, which bring together thousands of exhibitors and visitors. Initially, they played only commercial function. But with time they also adopted the function of information and promotion, allow to reach genuinely interested clients in your offer. Additionally they offer the possibility of contact with customers in order to receive their opinions and reactions to products, especially for new ones that have yet to be subject to manufacturing or services. This interaction has many benefits, which don't provide other forms of marketing. They are also a form of communication and creating the image of the company and for many entrepreneurs are also a point of gathering information about the industry, competition, needs and customers' preferences. At the

How to cite this book chapter:

Duda, J. and Lelek, Ł. 2019. Case 1: A professional online exhibition platform as an example of final user's benefits. In: Gąsior, A. (ed.) Pro-ecological Restructuring of Companies: Case Studies, Pp. 183-198. London: Ubiquity Press. DOI: https://doi. org/10.5334/bbk.p. License: CC-BY 4.0 
fair the latest innovative achievements are presented. Trade and business plays an important role not only in the life of companies, but also in the life of cities. Today's business events, trade fairs and conferences are very different from what was organized in the last century. Due to the strong specialization, they are mainly industry events on narrow topics, often combined with seminars and expert meetings, during which all kinds of novelties are present. The largest trade fair centers in Poland are Poznan, Kielce, Warsaw, Łódź, Gdańsk, Kraków and Lower Silesian agglomeration. Trade is popular not only in Poland but all over the world. The largest known centers include Hanover, Milan, Frankfurt, Cologne, Duesseldorf, Chicago, Valencia, Paris, Birmingham, Berlin, Nuremberg, Leipzig and Brno.

The dynamically changing global market currently puts new demands on businesses. Consumers expect from them not only competitive, but innovative products in terms of ecological and cost and activities that would be considered by society as responsible. According to the definition of the European Commission, corporate social responsibility is an including, on voluntary basis, by the enterprise, social and environmental issues in their business, going beyond the legal requirements and contractual obligations. Therefore, there are many areas of social responsibility, eg. economic, sociological, ecological, ethical, legal and philanthropic.

On the one hand, enterprises are forced to reduce the cost of business in order to be competitive in the market, and on the other hand, the attitude of customers are becoming strongly pro-ecological. Corporate social responsibility means that more and more companies treat environmental and social aspects not only as secondary activities, but as one of the main objectives of their strategy. It is not just to follow trends, but entrepreneurs also have begun to see a lot of benefits that result from environmental initiatives. Given the changes in the climate, these actions are becoming more important in business. Therefore, the aim of this paper is the presentation of an innovative platform for an online trade fair, which lowers the costs of participation in trade fairs, conferences and business meetings and is an example of good practice in environmental and social activities.

\section{Business Tourism as a Tool for Supporting Business Innovation}

In Poland, business tourism is a young but rapidly growing industry that is an important segment of the tourism market. Poland's accession in 2004 to the EU and central geographical position stimulate the number of business meetings in our country. Economic development and internationalization of the economy led to an increase in the number of foreign investors contributing to the need for the development of the Meeting-Incentive-Conferences-Event (MICE) industry. However, Poland as a place for international meetings, conferences 
and congresses for the European MCIE industry is still a new and attractive destination. According to the report prepared by Institute of Tourism in 2011, the number of arrivals business in Poland was estimated at 3.5 million, increasing the advantage over the arrivals for tourist-recreational purposes (about 3.1 million - the data for the first three quarters of the year). However, according to data published by the Association of Conferences and Congresses in Poland (2013) by business arrivals remained at the level of 4.3-5.2 million per year. Business purpose represents therefore $30 \%$ of all tourist visits in Poland, where more than $40 \%$ of them combine business with other aims. Therefore, at the European, national and regional level and national institutions, governments, businesses, hotels and convention centres compete with each other for the greatest number of customers in the field of organized events. To meet the market requirements, specific information is needed, including research and analysis of statistical data. Among the global institutions engaged in the evaluation and rankings of business tourism the following should be mentioned:

- UIA (Union of International Association)

- ICCA (International Congress and Convention Associations)

- UNWTO (World Tourism Organization)

- The Global Association of the Exhibition Industry

The data are collected mainly by the Poland Convention Bureau (PCB), Hotel Market Institute and the Institute of Tourism, whose statistics are based on data compiled by the regional convention bureaux and conference facilities. Depending on the assumptions and criteria, e.g. the number of participants and duration of the event (referred as conference or congress), the data may largely differ from each other (Table 1).

Poland has quite a high position at the forefront of business tourism, which is increasing every year (in 2010 - 32 with 98 meetings, according to a report by the ICCA). In addition, you may notice that the dominant places for meetings and congresses are Warszawa and Krakow.

Analysing the national data in this regard the number of included meetings, conferences and conventions is significantly higher than that resulting from international statistics. This is due the criteria, which take into account the typical national meetings. According to data published in 2011 (Table 2), the number of meetings amounted to a total of 24,843, and at the forefront of the cities where these meetings took place were Warszawa, Krakow and Trojmiasto. Warszawa has a predominance of hundreds of meetings over the Krakow. These meetings corresponded for a total of $88 \%$ of all identified events in the national ranking (Borodako et al. 2014).

It should be noted that in 2012 the standardized methodology for data collection in the field of national statistics on the tourism business was introduced, so these results are subject to a methodological lapse, e.g. the methodology of identifying the meetings in Krakow, differed from that used by the PCB for other cities. 
Table 1: Poland and individual cities in the rankings of ICCA (International Congress and Convention Association) and UIA (Union of International Associations) in 2011.

\begin{tabular}{|c|c|c|}
\hline $\begin{array}{l}\text { International } \\
\text { organizations }\end{array}$ & ICCA & UIA \\
\hline $\begin{array}{l}\text { The criteria } \\
\text { for carried out } \\
\text { rankings }\end{array}$ & $\begin{array}{l}\text { - meetings are held } \\
\text { periodically } \\
\text { - focus a minimum of } \\
50 \text { participants } \\
\text { - participants from at least } \\
3 \text { different countries }\end{array}$ & $\begin{array}{l}\text { - meetings last at least } \\
3 \text { days } \\
\text { - focus a minimum of } \\
300 \text { participants } \\
\text { - participants come from a } \\
\text { minimum of } 5 \text { different } \\
\text { countries } \\
\text { - At least } 40 \% \text { of the } \\
\text { participants come from } \\
\text { abroad }\end{array}$ \\
\hline $\begin{array}{l}\text { Place of Poland in } \\
\text { the global rankings } \\
\text { in } 2011\end{array}$ & 21 & 23 \\
\hline $\begin{array}{l}\text { Cities with the } \\
\text { largest number of } \\
\text { meetings }\end{array}$ & $\begin{array}{l}\text { 1. Warszawa }-65 \text { meetings } \\
\text { 2. Krakow }-40 \text { meetings } \\
\text { 3. Gdansk }-23 \text { meetings } \\
\text { 4. Wroclaw }-10 \text { meetings } \\
\text { 5. Poznan }-8 \text { meetings }\end{array}$ & $\begin{array}{l}\text { 1. Warszawa }-40 \text { meetings } \\
\text { 2. Krakow }-30 \text { meetings } \\
\text { 3. Gdansk }-12 \text { meetings } \\
\text { 4. Wroclaw }-7 \text { meetings } \\
\text { 5. Poznan }-6 \text { meetings }\end{array}$ \\
\hline
\end{tabular}

Source: N. Tomczyk, Zarządzanie turystyka biznesowa na przykładzie wybranych convention bureaux w Polsce, Praca magisterska, Instytut Geografii Miast i Turyzmu, Uniwersytet Łódzki, 2013.

Table 2: The number of meetings within group business tourism in selected Polish cities in 2011year.

\begin{tabular}{|l|r|r|}
\hline \multicolumn{1}{|c|}{ City } & Number of meetings & \multicolumn{1}{|c|}{ Share [\%] } \\
\hline Warszawa & 8830 & 33.5 \\
\hline Krakow & 8304 & 33.4 \\
\hline Trojmiasto & 4773 & 19.2 \\
\hline Katowice & 900 & 3.6 \\
\hline Poznan & 766 & 3.1 \\
\hline Bydgoszcz & 496 & 2.0 \\
\hline Wroclaw & 440 & 1.8 \\
\hline Torun & 334 & 1.3 \\
\hline Summary & 24,843 & 100.0 \\
\hline
\end{tabular}

Source: K. Borodako, Turystyka biznesowa w Krakowie na tle wybranych miast polskich, Prace Geograficzne, zeszyt 134, Instytut Geografiii Gospodarki Przestrzennej UJ. 
Analysing the tourism business in particular, regional data for 2012 show a slightly different situation from that presented directly for the cities. The business meetings in Poland reached the level of 22,300 events, of which 10,622 were congresses and conferences, 5305 were incentive events, 4657 were corporate events, and 1716 were fairs and exhibitions. The data presented by the PCB confirm the dominance of Warsaw, Mazowieckie region (Figure 1). However, the position of individual regions and cities in the rankings of business tourism is dependent on many factors, the following being the dominant factors:

- tourist popularity and recognisability of the city in the world

- popularity in various environments, i.e. the scientific, economic and administrative

- promotional activities of the region and the city

An available infrastructure is also important, including technical and formal background, such as the number of hotels in a given business segment, e.g. the standard of the 4- and 5-star, the number of available rooms, meeting rooms and convention centres. Another factor is accessibility, which is especially

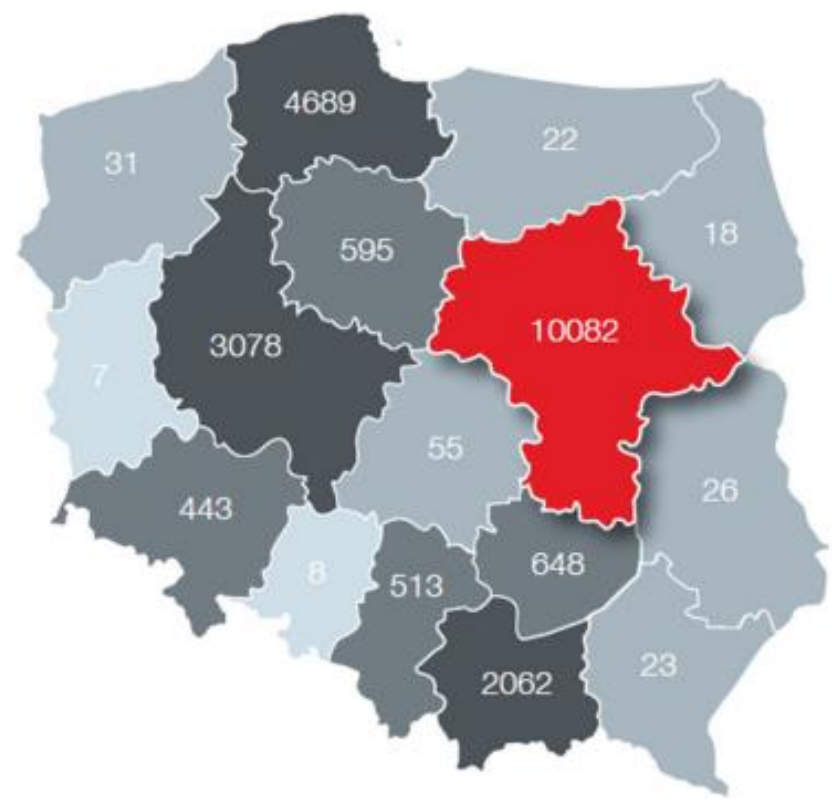

Fig. 1: The number of meetings and events with the division into voivodeships in 2012.

Source: K. Celuch, Raport „Przemyst spotkań i wydarzeń w Polsce - Poland Meetings and Events Industry Report 2013”, PCB, Warszawa, 2013. 
important in the case of international events. In this case, a complement of flights is important, and there also should be good bus, rail and metro lines. Additionally, each industrial sector is characterized by their own criteria, which determine the choice of the place of venues and events. For the research sector, which is an important segment of the meetings industry, mainly due to the popularity of conferences, congresses and conventions, an important factor is functioning in a place such as research institutes. This is due to the fact that this research centres are largely responsible for the organization of such events, and in most cases they choose their own technical facilities, including meeting and conference rooms. Many more factors, determining the popularity of the site, can be identified. They are also dependent on individual industries benefiting from the tourism business (Borodako et al. 2014).

Statistical data show that the MICE sector is an important segment of the national economy and that every year it becomes more and more important in the overall structure of tourism in Poland.

\section{Economic Aspects of the Example of Krakow City}

The economic importance of the meetings industry is closely related to the amount of events organized in a particular place. In the case of Krakow, in 2013, 3413 meetings took place there, of which three-quarters were held in hotels, and a quarter had an international character. For the most part these meetings were a conference or convention, and $70 \%$ of them were organized by the company in the technic and IT branch.

The cost of participation in conferences, congresses and training accounted for an average amount of 2098 PLNs (including all the costs, i.e. participation, accommodation, personal expenses etc.), while in fairs and exhibitions it was 1023 PLNs. The costs for the issuer of the trade fair stood at 15,791 PLNs and for the representing person 2439 PLNs, which accounted for individual spending. In 2013, the meetings industry generated 1,068.9 million PLN in Krakow, which accounted for $2.37 \%$ of Krakow's GDP. Proceeds to the city budget in the form of taxes and fees amounted to 89 million PLNs (2.4\% of budget revenues of Krakow). This contributed to the creation of over 12 thousand year-round jobs and 316 million PLN of earnings for workers employed in this industry (Borodako et al. 2014).

\section{Organisation of Ecological Business Events, and the Benefits for Users}

The perception of the benefits from involvement in environmental initiatives and doing business with in a way that society considers as a responsible are becoming more frequent practice among Polish entrepreneurs. Companies are beginning pay attention to pro-environmental aspects of their activities and 
fit the principles of sustainable development in their strategy. In the case of the MICE industry, it is related to an increase in events organized in a sustainable and environmentally friendly manner, including conferences, exhibitions, workshops etc. The main idea of this approach is to minimize the environmental impact of the event at every stage of its implementation. An intermediate goal can be, for example, raising awareness of the participants in terms of proenvironment and effective management of resources and materials.

A change of approach and thinking in the field of environmental activities may contribute to measurable and visible benefits for the company. In the long term, taking care of the environment can contribute to cost savings and a positive image of a company, which can increase its competitiveness on the market (Kostecka, Pączka \& Piękoś 2013).

Increasing economic and environmental efficiency by minimizing the use of resources and energy and reduce the amount of waste generated are actions that distinguish sustainable events. Reduced costs and waste generation can be achieved by, for example, the introduction of programs in the field of energy efficiency (hotels, conference centres), reducing the amount of printed materials, and the use of local or ecological food. In addition, eliminating the transport, such as by locating events within walking distance of the major transportation hubs, or the maximum use of daylight can contribute to further cost reduction.

The possibility of minimizing expenses associated with the organization of events, meetings and conferences in a sustainable way is undoubtedly a major factor in the growing interest in this approach. However, aspects of environmental and social responsibility should be taken into account at the same level. So, in order to treat an event as an ecological, there should be more segregation of waste or use of biodegradable cups. Such an event should be organized in accordance with the formal environmental standards, which take into account all factors that could have an impact on the environment. The concept that allows for an assessment of the services or processes in field of environmental impact is the Life Cycle Assessment (LCA). LCA is part of a broader concept known as lifecycle management (LCM). According to this idea the products and services should be designed, evaluated and compared with each other through the prism of all stages within their whole life cycle. This allows for a better understanding of a particular service or product, as it requires us to examine the issue of environmental, social and economic factors, which are associated with both before (supply chain) production and post-production stages.

A good example of cost reduction can be organized every year in the Vienna International AIDS Conference. In 2010, its organizers decided to change the organization system and take environmental activities into account and estimate the costs that could be saved thanks to them. The conference in 2010 attracted more than 19,000 participants, and achieved reduced costs of:

-33,000 USD by eliminating the printing of invitations and brochures, for the benefit of electronic shipping, 
- 20,000 USD by printing a summary book on request only,

-500,000 USD by resignation of providing an airport transfer and encouraging the use of public transport (offering a 30\% discount on the price of public transport tickets), and

-50,000 USD by using tap water instead of bottled for delegates.

In total, these actions contributed to a savings of 603,000 USD in comparison to the conference in previous years (Sustainable Events Guide 2012).

Another good practice is developed by the UNEP model for estimating and budget management, travel and business delegations. Each time you purchase travel tickets, a model based on the means of transportation and details of the route generates the carbon footprint of the journey and calculates an additional fee, which is charged to the same budget lines as expenses. The money collected in this way is then sent monthly to the UNEP Climate Neutral Fund and used for environmental activities, in order to offset greenhouse gas emissions arising during the trips. In this case, it generates additional costs for meetings, but helps to improve the image of the company and in the long term can contribute to economic benefits, e.g. increased competitiveness.

A very interesting example of the environmental and economic benefits is also presented below innovative platform for online trade fair, built by Future Expo Sp. z o.o.

\section{Event organisation}

Each customer buying any package rents, for the duration of the fair, an e-stand, which is posted by its logo and which is matched to the supplied graphics, files and information. During the time of the fair, a customer receives at a unique Skype address by which they will be able to negotiate and present the company offer live. There is also the possibility of designing the stands in a foreign language opening the possibility for the international market. The online fair platform, Future Expo Sp. z o.o. offers various packages, which are presented in Table 3:

Table 3: Cost of participation in the online fair.

\begin{tabular}{|l|l|c|}
\hline Package name & \multicolumn{1}{|c|}{ Description } & Costs \\
\hline BASIC & $\begin{array}{l}\text { - e-stand } \\
\text { - the table of contact details }\end{array}$ & $600 \mathrm{zl}$ \\
& $\begin{array}{l}\text { - box with a description of the business } \\
\text { - box with a place on the content of the company's offer }\end{array}$ & \\
& $\begin{array}{l}\text { - database of companies taking part in trade fairs } \\
\text { - Skype account integrated with e-stand }\end{array}$ & \\
& - 3 links for outside the website & \\
\hline
\end{tabular}




\begin{tabular}{|c|c|c|}
\hline Package name & Description & Costs \\
\hline PRO & $\begin{array}{l}\text { - e-stand } \\
\text { - the table of contact details } \\
\text { - box with a description of the business } \\
\text { - box with a place on the content of the company's offer } \\
\text { - database of companies taking part in trade fairs } \\
\text { - Skype account integrated with e-stand } \\
\text { - } 5 \text { links for outside the website } \\
\text { - } 1 \text { GB of cloud storage for customers files } \\
\text { - business card in the catalog of enterprise } \\
\text { - sending the offer/presentation to all participants of the } \\
\text { fair }\end{array}$ & $1200 \mathrm{zl}$ \\
\hline PREMIUM & $\begin{array}{l}\text { - e-stand } \\
\text { - the table of contact details } \\
\text { - box with a description of the business } \\
\text { - box with a place on the content of the company's offer } \\
\text { - database of companies taking part in trade fairs } \\
\text { - Skype account integrated with e-stand } \\
\text { - } 5 \text { links for outside the website } \\
\text { - } 3 \text { GB of cloud storage for customers' files } \\
\text { - business card in the catalog of enterprise } \\
\text { - sending the offer/presentation to all participants of the } \\
\text { - fair } \\
\text { - pago "Industry Leader" } \\
\text { - Advertising on the home page (advertising banner) } \\
\text { - Certificate The Leader of Future Expo Fair }\end{array}$ & $1800 \mathrm{zł}$ \\
\hline
\end{tabular}

Source: Elaboration on the basis of materials supplied by the Future Expo Sp. z o.o. company.

The organization of online trade fairs offers many benefits, the most common include:

- the ability to simultaneously present in the country and abroad,

- low costs of participation in trade fairs,

- building business relationships in a modern way,

- knowing the competition,

- expansion of the customer portfolio,

- modern forms of information exchange,

- increased competitiveness,

- direct contact with client,

- strengthening of position,

- time savings resulting from staying at the office, 
- financial savings related to the delegations of workers to traditional fairs, the costs of travel, accommodation etc., and

- no costs associated with renting facility, hiring technical staff, catering, printing promotional materials etc.

In addition, attention should be paid to the environmental benefits, which include the fact that:

- online fair does not generate waste,

- organization of meetings online generate significant less amounts of electricity than full infrastructure of direct meetings,

- online fair does not generate direct water use and do not require the services of catering and cleaning, and

- there is no need to use any way of transport - fuel savings and less pollution.

A more detailed economic analysis of the events organized in the traditional manner, taking into consideration environmental aspects as well as online, is presented below.

\section{Economic analysis of ecological events organizing}

The methods of economic analysis can include a number of financial indicators, ie. ROI, NPV, IRR, which are gaining use in assessing the efficiency of investment, not only financial, but also investments in the enterprises. However, in the case of ecological events we are not dealing with an ordinary investment, therefore it was decided to use profit and loss to account for economic analysis. It is a comparison of generated revenue, such as from grants, sponsorships, conference fees etc., in a given period with costs incurred during the organization of the event. According to the Accounting Act in the profit and loss analyses the financial result is determined in a "ladder", showing income and expenses and profits and losses separately. Table 4 presents a template showing examples of types of entries. Please note that the budget depends largely on the specifics of the event.

Table 4 presents costs that are expenses of one of the conferences organized by PAN MEERI. ${ }^{1}$ The budget does not include the proceeds, since the aim was to show the possibility of reducing expenditure. In this example it is assumed that the costs were planned to actual expenditure. The table summarizes the reduction or increase in costs relating to the organization of the event itself, however, taking into consideration environmental and social aspects. The assumptions for the calculation are shown in Table 5. 
Table 4: Comparison costs of events held in the ordinary way and taking into account the environmental and social aspects.

\begin{tabular}{|c|c|c|c|c|c|}
\hline \multicolumn{2}{|r|}{ Description } & $\begin{array}{l}\text { Expenditure } \\
\text { ordinary } \\
\text { event }[\mathrm{PLN}]\end{array}$ & $\begin{array}{c}\text { The } \\
\text { possibility } \\
\text { of reduction } \\
\text { / increase of } \\
\text { costs [\%] }\end{array}$ & $\begin{array}{c}\text { Expenditure } \\
\text { ecological } \\
\text { event }[\mathrm{PLN}]\end{array}$ & $\begin{array}{l}\text { On } \\
\text { line } \\
\text { event }\end{array}$ \\
\hline \multicolumn{3}{|c|}{ INCOME } & & & \\
\hline 1. & Subsidies, public funding & - & - & - & - \\
\hline 2. & Sponsors & - & - & - & - \\
\hline 3. & Conference fees & - & - & - & - \\
\hline 4. & Advertising stands & - & - & - & - \\
\hline 5. & Other income & - & - & - & - \\
\hline 6. & TOTAL INCOME & - & - & - & - \\
\hline \multicolumn{3}{|c|}{ EXPENDITURE } & & & \\
\hline \multicolumn{3}{|c|}{ ADMINISTRATION } & & & \\
\hline 1. & Administrative costs & 6011 & - & 6011 & 5200 \\
\hline 2. & Management costs & 8363 & - & 8363 & 24,300 \\
\hline 3. & Insurance costs & - & - & - & \\
\hline 4. & $\begin{array}{l}\text { Delegations and } \\
\text { accomodation }\end{array}$ & 13,376 & $-38 \%^{1}$ & 8293 & 2400 \\
\hline 5. & Salary and Fees & 33,380 & - & 33,380 & 43,400 \\
\hline 6. & $\begin{array}{l}\text { Other administrative } \\
\text { expenses }\end{array}$ & - & - & - & - \\
\hline 7. & $\begin{array}{l}\text { TOTAL } \\
\text { ADMINISTRATION } \\
\text { EXPENDITURE }\end{array}$ & 61,130 & - & 56,047 & 75,300 \\
\hline \multicolumn{3}{|c|}{ EXPENSES OF EVENTS } & & & \\
\hline 1. & $\begin{array}{l}\text { Costs of preparing } \\
\text { requests for proposals / } \\
\text { tenders }\end{array}$ & - & - & - & \\
\hline 2. & Cost of rental & 17,404 & - & 17,404 & 0 \\
\hline 3. & $\begin{array}{l}\text { Other operating costs } \\
\text { (rental of equipment, } \\
\text { technical personnel, etc.). }\end{array}$ & 16,922 & - & 16,922 & \\
\hline 4. & Security and safety & - & - & - & \\
\hline 5. & Insurance & - & - & - & \\
\hline 6. & $\begin{array}{l}\text { Catering costs/banquet/ } \\
\text { dinner }\end{array}$ & 63,641 & $+30 \%^{2}$ & 82,733 & \\
\hline
\end{tabular}

Continued. 


\begin{tabular}{|c|c|c|c|c|c|}
\hline \multicolumn{2}{|c|}{ Description } & \multirow{2}{*}{\begin{tabular}{|r}
$\begin{array}{c}\text { Expenditure } \\
\text { ordinary } \\
\text { event [PLN] }\end{array}$ \\
3234
\end{tabular}} & \multirow{2}{*}{$\begin{array}{c}\text { The } \\
\text { possibility } \\
\text { of reduction } \\
\text { / increase of } \\
\text { costs [\%] } \\
-90 \%^{3}\end{array}$} & \multirow{2}{*}{$\begin{array}{r}\begin{array}{c}\text { Expenditure } \\
\text { ecological } \\
\text { event [PLN] }\end{array} \\
323\end{array}$} & \multirow{2}{*}{$\begin{array}{r}\begin{array}{c}\text { On } \\
\text { line } \\
\text { event }\end{array} \\
0\end{array}$} \\
\hline 7. & $\begin{array}{l}\text { Transportation of } \\
\text { participants }\end{array}$ & & & & \\
\hline 8. & $\begin{array}{l}\text { Entertainment/artistic } \\
\text { programs/study visits }\end{array}$ & - & - & - & \\
\hline 9. & Accommodation & 11,000 & $+30 \%^{4}$ & 14300 & 0 \\
\hline 10. & $\begin{array}{l}\text { Preparing invitations/ } \\
\text { tickets }\end{array}$ & 5754 & $-70 \%^{5}$ & 1726,2 & 0 \\
\hline 11. & Other expenses & 1230 & - & 1230 & \\
\hline 12. & Translator & 20,824 & - & 20824 & 6150 \\
\hline 13. & TOTAL & 140,009 & - & 155462 & 6150 \\
\hline \multicolumn{6}{|c|}{ MARKETING AND PROMOTION } \\
\hline 1. & $\begin{array}{l}\text { Advertising - Media and } \\
\text { PR }\end{array}$ & 38,227 & $-50 \%{ }^{6}$ & 19,113 & 9400 \\
\hline 2. & Promotional gadgets & - & - & - & \\
\hline 3. & $\begin{array}{l}\text { Design and } \\
\text { implementation of } \\
\text { electronic materials on } \\
\text { CD, DVD, etc. }\end{array}$ & 8790 & $-100 \%^{7}$ & 0 & 0 \\
\hline 4. & $\begin{array}{l}\text { Design and print } \\
\text { promotional/technical } \\
\text { materials }\end{array}$ & 95,672 & $-100 \%^{8}$ & 0 & 0 \\
\hline 5. & $\begin{array}{l}\text { Distribution of e-mail/ } \\
\text { brochure/information }\end{array}$ & 766 & $-70 \%{ }^{9}$ & 229.8 & 450 \\
\hline 6. & Website & 5696 & - & 5696 & \\
\hline 7. & Other expenses & - & - & - & \\
\hline 8. & \multirow[t]{2}{*}{ Offset of $\mathrm{CO}_{2}$ emissions } & \multirow[t]{2}{*}{0} & $\begin{array}{l}\text { offset } 50 \\
\text { years } \\
+100 \% \%^{10}\end{array}$ & 10,680 & 0 \\
\hline 9. & & & $\begin{array}{l}\text { offset } 30 \\
\text { years } \\
+100 \%^{10}\end{array}$ & 52,955 & 0 \\
\hline 10. & \multirow[t]{2}{*}{ TOTAL } & \multirow[t]{2}{*}{149,151} & $\begin{array}{l}\text { offset } 50 \\
\text { years }\end{array}$ & 35,719 & 0 \\
\hline 11. & & & $\begin{array}{l}\text { offset } 30 \\
\text { years }\end{array}$ & 77,994 & 0 \\
\hline
\end{tabular}




\begin{tabular}{|c|c|c|c|c|}
\hline Description & $\begin{array}{c}\text { Expenditure } \\
\text { ordinary } \\
\text { event }[\mathrm{PLN}]\end{array}$ & $\begin{array}{c}\text { The } \\
\text { possibility } \\
\text { of reduction } \\
\text { / increase of } \\
\text { costs [\%] }\end{array}$ & $\begin{array}{c}\text { Expenditure } \\
\text { ecological } \\
\text { event }[\mathrm{PLN}]\end{array}$ & $\begin{array}{c}\text { On } \\
\text { line } \\
\text { event }\end{array}$ \\
\hline \multirow[t]{2}{*}{ TOTAL EXPENDITURE } & \multirow[t]{2}{*}{350,290} & $\begin{array}{l}\text { offset } 50 \\
\text { years }\end{array}$ & 247,228 & \multirow[t]{2}{*}{91,300} \\
\hline & & $\begin{array}{l}\text { offset } 30 \\
\text { years }\end{array}$ & 289,503 & \\
\hline \multirow[t]{2}{*}{$\begin{array}{l}\text { UNFORESEEN EXPENSES } \\
\text { ( } 5 \% \text { of total costs) }\end{array}$} & \multirow[t]{2}{*}{17,515} & $\begin{array}{l}\text { offset } 50 \\
\text { years }\end{array}$ & 12,361 & \multirow[t]{2}{*}{4565} \\
\hline & & $\begin{array}{l}\text { offset } 30 \\
\text { years }\end{array}$ & 14,475 & \\
\hline \multirow[t]{2}{*}{ TOTAL } & \multirow[t]{2}{*}{367,805} & $\begin{array}{l}\text { offset } 50 \\
\text { years }\end{array}$ & 259,589 & \multirow[t]{2}{*}{95,865} \\
\hline & & $\begin{array}{l}\text { offset } 30 \\
\text { years }\end{array}$ & 303,978 & \\
\hline Surplus / deficit & - & - & - & - \\
\hline
\end{tabular}

Source: Report, Analiza ekonomiczna wybranych inicjatyw ekologicznych w branży MICE, Project Zielona Energia Zmiany Społecznej, Program Social Innovation funded by the National Centre for Research and Development in Poland.

Table 5: The assumptions for the calculations in Table 4.

\begin{tabular}{|c|c|}
\hline \multicolumn{2}{|r|}{ Assumption } \\
\hline 1 & $\begin{array}{l}\text { 50\% journey took place with a private car, } \\
\text { - cost of travel by private car at a distance of } 100 \mathrm{~km} \text { is } 83.58 \mathrm{PLN} \text { (at the rate } \\
\text { of } 0.8358 \text { PLN/km) } \\
\text { - the cost of the bus on the same route is } 15 \mathrm{PLN} \text {, and the cost of train } 22 \text { PLN, } \\
\text { the average for public transport }(100 \mathrm{~km}) \text { to } 19.50 \text { PLN } \\
\text { Source of prices: http://wartowiedziec.org/attachments/article/22417/ } \\
\text { Plan_zrownowazonego_rozwoju_publicznego_transportu_zbiorowego_dla_ } \\
\text { wojew\%C3\%B3dztwa_do }\end{array}$ \\
\hline 2 & $\begin{array}{l}\text { it was assumed that the cost of organic food is } 30 \% \text { higher } \\
\text { Source: http://greendietbuffet.pl/produkty-ekologicznie-zdrowsze-czy-tylko- } \\
\text { drozsze/ }\end{array}$ \\
\hline 3 & it was assumed that $90 \%$ participants use public transport \\
\hline 4 & $\begin{array}{l}\text { it was assumed that the average cost of a standard room in hotels of the with } \\
\text { one to four stars, with green certificate is about } 30 \% \text { higher than in the objects } \\
\text { of the same type without this certificate. Data was established on the basis } \\
\text { of: Nicolai V. Kuminoff, Congwen Zhang, and Jeta Rudi } 2010 \text { Are Travelers } \\
\text { Willing to Pay a Premium to Stay at a "Green" Hotel? Evidence from an } \\
\text { Internal Meta-Analysis of Hedonic Price Premia. Agricultural and Resource } \\
\text { Economics Review, 39(3): 468-484. }\end{array}$ \\
\hline
\end{tabular}




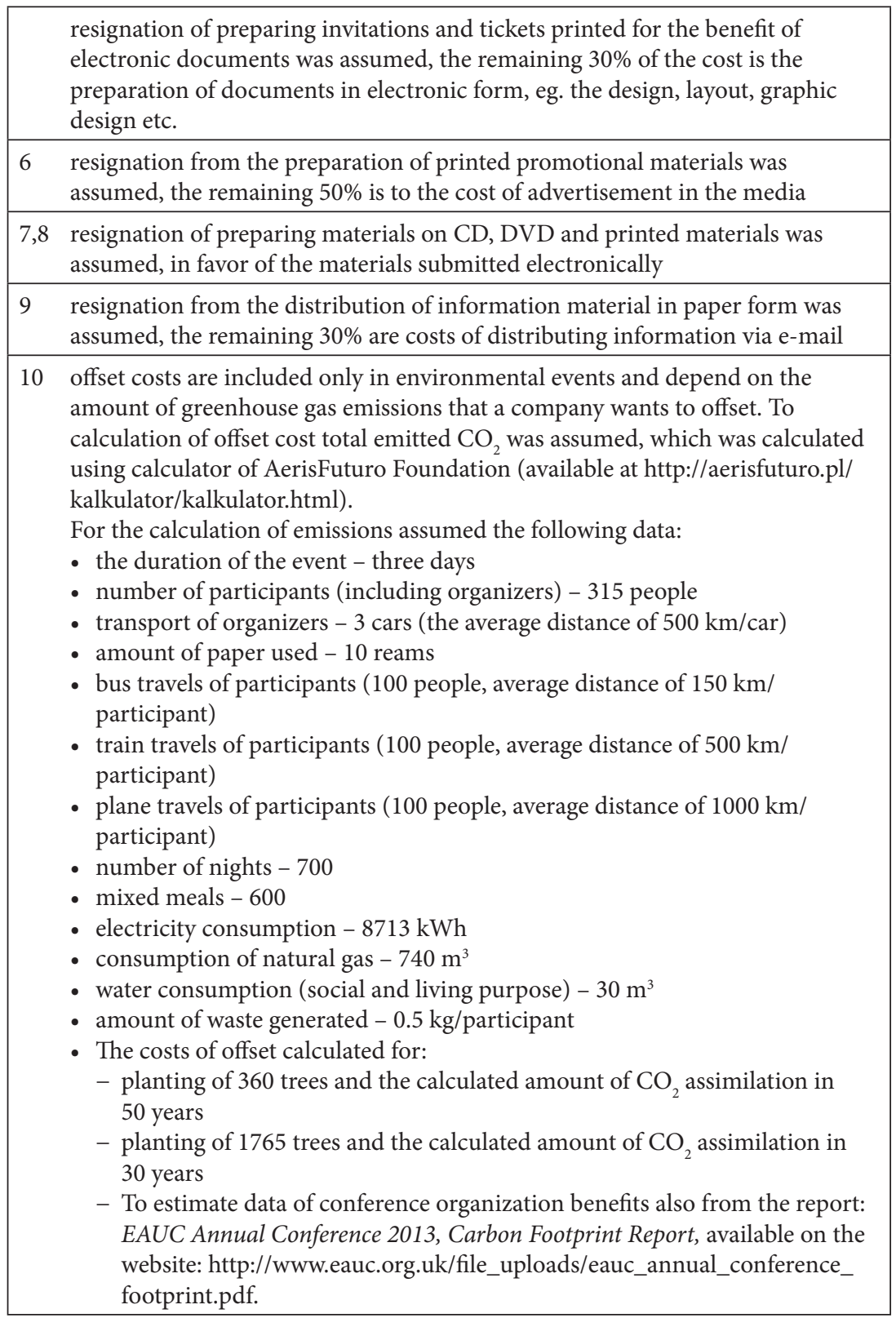

Source: Report, Analiza ekonomiczna wybranych inicjatyw ekologicznych w branży MICE, Project Zielona Energia Zmiany Społecznej, Program Social Innovation funded by the National Centre for Research and Development in Poland. 


\section{Conclusions}

Trade and business meetings are an important part of business, ranging from antiquity to the present day. The global market and rapidly changing environment require changes in the functioning of modern enterprises, including reduction of costs and adaptation to changing customers' tastes and preferences. Businesses are trying to meet these expectations by seeking access to widely understood business information. Fairs, conferences and business meetings are places where this kind of information is available. Therefore, this study shows the benefits of online trade fairs and compared the costs to that of similar events organized in the traditional way.

According to the data presented above, organizing an event in ecologically friendly manner can bring environmental, social and economic benefits. It builds a good image of the company and shows the company's innovation. Organizing business meetings online is still cheaper and gives a number of additional environmental and social benefits. According to the data presented in Table 3, costs of participation in online trade fairs are small, depending on the package range from 600 PLN to 1800 PLN, which results from the fact that the cost of organizing such events represents one third of the cost of traditional meetings and are about $60 \%$ lower than face-to-face green events.

Taking into account that many companies are expanding their markets by looking for business partners not only in the country but in the whole world, building their branches abroad, the possibility of contacts online is particularly important. It allows for direct contact with customers, suppliers and cooperatives, saving cost, time and environmental impact.

\section{Notes}

${ }^{1}$ Instytut Gospodarki Surowcami Mineralnymi i Energią Polskiej Akademii Nauk.

\section{References}

Aeris Futuro Foundation. The Aeris Futuro Foundation's CO2 Calculator. Available at URL http://aerisfuturo.pl/kalkulator/kalkulator.html [Last accessed 01.10.2016].

Borodako, K, Berbeka, J, Niemczyk, A, and Seweryn R 2014 Raport: Ekonomiczne znaczenie przemystu spotkań dla gospodarki Krakowa, Kraków, wrzesień.

Borodako, K 2013 Turystyka biznesowa w Krakowie na tle wybranych miast polskich, Prace Geograficzne, zeszyt134, InstytutGeografiiiGospodarkiPrzestrzennejUJ. 
Celuch, K 2013 Raport „Przemysł spotkań i wydarzeń w Polsce - Poland Meetings and Events Industry Report 2013", PCB, Warszawa.

Gerega, A 2010 Rachunek zysków $i$ strat $w$ prawie bilansowym $i$ w regulacjach międzynarodowych, Studenckie Naukowe Czasopismo Internetowe TH!NK, Nr 1 (2) s. 15-24, Akademia Górniczo-Hutnicza, Wydział Zarządzania.

Greenstonecarbon 2013 Report: EAUC Annual Conference 2013, Carbon Footprint Report, dostęny na stronie Available at http://www.eauc.org.uk/file_ uploads/eauc_annual_conference_footprint.pdf [Last accessed 15.10.2016]. Kostecka, J, Pączka, G, and Piękoś, P 2013 Prośrodowiskowe zasady organizacji konferencji, Inżynieria i Ochrona Środowiska, t. 16, nr 4, s. 499-510.

Sustainable events guide 2012 United Nations Environment Programme.

Tomczyk, N 2013 Zarządzanie turystyka biznesowa na przykładzie wybranych convention bureaux w Polsce, Praca magisterska, Instytut Geografii Miast i Turyzmu, Uniwersytet Łódzki. 